\title{
MANITOBA BREEDING RANGE EXTENSION AND LARGE CLUTCH SIZE FOR AN AMERICAN AVOCET
}

WILLIAM, H. KOONZ, Wildlife Branch, Box 14, 1495 St. James Street, Winnipeg, Manitoba. R3H OW9

On 17 June 1984, Don Campbell, Terry Campbell and I visited a low rocky island along the west shore of Kawinaw Lake $\left(52^{\circ} 48^{\prime} \mathrm{N}, 99^{\circ} 31^{\prime} \mathrm{W}\right)$. The island contained some 35 Common Terns and a colony of roughly 40 American Avocets in breeding plumage. All but one of the 13 avocet nests checked contained four eggs. This odd nest was larger, had a thicker base and contained seven eggs (see photo). The size and thickness of the nest suggests a combined effort of two females rather than a large clutch or dump nest.

This breeding record represents a northeastward extension of $160 \mathrm{~km}$ (100 mi.) for the American Avocet in Manitoba, and documents an abnormally large clutch size. The American Avocet is known to produce large clutches on the Canadian Prairies, although, to my knowledge, no previous large clutch record exists for Manitoba. Farley, Vermeer and Kondla all describe large clutches for Alberta and Saskatchewan. ${ }^{135}$ Kondla's description suggests that two females were involved. What was at first one nest later was separated into two nests each containing four eggs, two of which were likely laid by each female. Kondla and Pinel looked at 228 Canadian nest records from several sources. Results showed that $61(22 \%)$ contained more than 4 eggs. ${ }^{4}$ None of 36 Manitoba nests contained more than four eggs. Hamilton, in his California and
Oregon studies of 1966 and 1967, stated "never did I find a nest which contained six or more eggs." Hamilton's breeding range map stopped short of Lake Manitoba for its northeastern boundary. ${ }^{2}$

'FARLEY, F.L. 1932. Birds of the Battle River region. Institute of Applied Arts Ltd., Edmonton

${ }^{2}$ HAMILTON, R.B. 1975. Comparative behavior of the American Avocet and the Black-necked Stilt (Recurvirostridae). Ornith. Monographs 17.

${ }^{3}$ KONDLA, N.G. 1977. An unusual American Avocet nest. Blue Jay 35(2):94-95.

${ }^{4}$ KONDLA, N.G. and H.W. PINEL. 1978. Clutch size of the American Avocet in the Prairie Provinces. Blue Jay 36(3):150-153.

${ }^{5}$ VERMEER, K. 1971. Large American Avocet clutches at Dowling Lake, Alberta. Blue Jay 29(2):88.

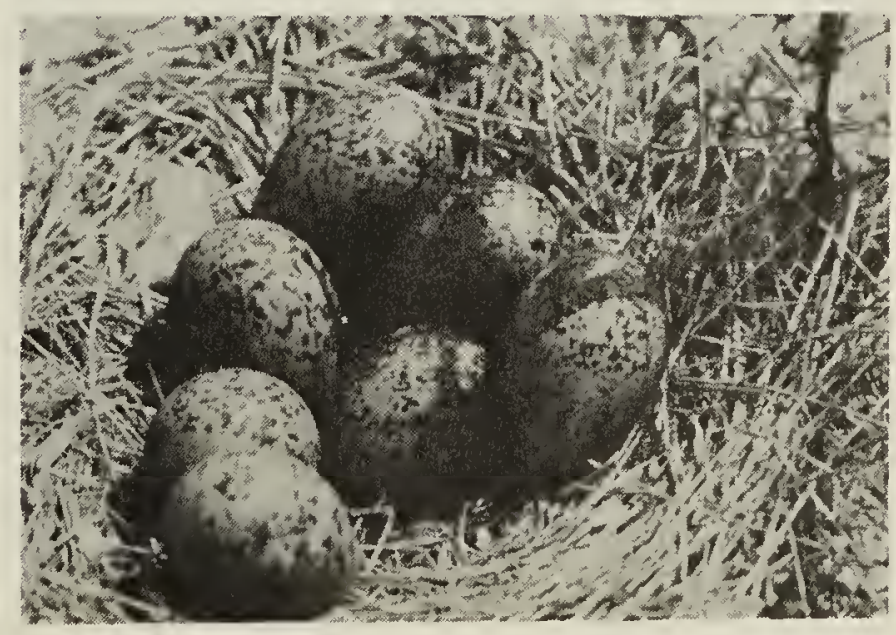

Avocet nest

W.H. Koonz 